\title{
Summary
}

Discussion of the common complications and pathology of the chalazion.

The customary operation of incision and curettage is not sufficient to effect a satisfactory permanent cure in long-standing or complicated cases; dissection and removal under novocaine infiltration anaesthesia is to be preferred.

Discussion of appropriate treatment for the various complications.

The author wishes to acknowledge his indebtedness to the honorary staff of Moorfields Eye Hospital for the material from which this paper has been prepared, and for their unfailing kindness and generous assistance at all times; and also to Mr. Law, pathologist to the hospital, for his encouragement and advice.

\section{EXPERIENCES OF A SUFFERER FROM WORD-BLINDNESS}

The BRIT. JL. OF OpHTHAL. has received the following note on the experiences of a patient suffering from wordblindness.

I HAVE been asked to write my experiences of word-blindness. I am not sure that I shall be able to convey the daily difficulties which this condition causes, partly because one unconsciously expects others to understand without explanation and also partly owing to the sufferer getting more or less used to the condition and consequently failing to analyse it.

My father and his only brother were both stammerers, their three sisters being normal. I had two brothers and a sister older than myself and a sister and brother younger than I. The governess who started us " took no trouble over me," "was bored with me because I was so slow," she told me this some 45 years later when I happened to meet her after that interval. Meanwhile, she had had a boys' school. She also volunteered that she knew now that she ought to have taken all the more trouble. "Reading without tears" was used for me, but without either of the desired results. My brothers and sisters went ahead-while I never got properly started. A German governess took her place when I was 7 years of age. She tried punishing me for being lazy and inattentive-which I am sure I was, for I found reading was so 
very difficult, almost impossible; the book was a blank and conveyed nothing to me and I was so weary with trying to learn to read. "Dunce," written in large black letters on a white cardboard hung on my back while I had to sit alone at the side table during luncheon with my back to the room-the butler and footman handing food looked on. I felt very foolish and selfconscious. I kept peeping round to see how they all took this exhibition.

I was quite sure I was an idiot or feeble-minded. And with those awful silent thoughts, I often cried in bed in the dark.

My mother offered to give me ten shillings if I would read a book. I tried to get through "Black Beauty." I was devoted to horses and this book about a pony attracted me. I worked away at it alone and with the governess month after month. I made a little " $\mathrm{V}$ " on the page to show how far I had got-I never finished the book or, of course, received the ten shillings, and "Black Beauty" is a nightmare to me.

Governesses came and went. A special one was employed for me alone in the hope that concentrated effort in a separate room might hasten my reading.

I was rather good at mental arithmetic and sums, and at these I beat my younger sister. Geography was a star turn for me and handcraft, and I "sewed beautifully."

Perhaps I was 12 years of age when I started going daily to Queen's College in Harley Street. In the reading class there, each girl had to read out loud a paragraph of about two inches of rather small print.

This lesson was simply agony to me, I dreaded it, my heart thumped from anxiety. I used to endeavour to sit in the back of the room and try to get the girl next to me to read my paragraph over to me in my ear, so that when my turn came I should know something about this wretched passage. Nevertheless, I made a lamentable exhibition of myself and I always failed to get the sense of the words I was trying to read. Neither did I ever know what the other girls had read, as I was worrying about my turn and paragraph. Sometimes this class was small in numbers and then I was forced to sit near the mistress-then the girl by my side could not help me as she would have been overheard. Just before my turn came I would scratch the inside of my nose and, having produced some blood, I was allowed to leave the room because "my nose was bleeding."

My mother has since told me that the Principal of Queen's College wrote to her to ask if my eyes were perhaps the cause of my difficulty in reading. I was duly seen by our family doctor who reported that there was nothing wrong. 
My mother says I was very sensitive and she had to treat me with kid gloves and that I did not easily get over being scolded by her, and that I would sulk for hours-so different from my sisters who would be in bounding spirits again in two minutes after being reprimanded.

I was 16 years of age when I went to a boarding school in Paris. I had great difficulty in reading the history set for prep. The Head held the history class in the dining-room-she sat at one end and I (as usual) sat at the other end. Madame was very kind to me and always threw me a counter (i.e., good mark) for my painful and inaudible answer. She made such wonderful good shots with those counters.

Not long after I married, in the course of conversation, my youngest brother said to my husband : "Oh, so you've discovered that she cannot read." I can read to myself very slowly, it is a physical effort. I tackle The Times daily. I think the shortness of the lines helps me, and I do not lose my place and my line quite sooften as I do when reading a book. Constantly I have to read the lines several times to get the sense. I have to read each word by itself. I do not use my lips. Long words I have to spell out and I generally fail to appreciate the different syllables of which the word is composed.

I am still very ashamed of my inability to read. I carry this dreadful secret always. I live in fear of having to read out something. At all costs I must conceal my ignorance-a habit which dates from my childhood.

There is another thing which makes my trouble worse, if I simply have to read out something, I get so agitated from a sense of fear that the written words hop about and splutter before my eyes and after the first paragraph all meaning is lost to me. I have an awful sensation of strain in my head.

I serve on several committees, both in London and in the country. Lately I was asked to be Chairman of one of the committees. I was very much pressed to take it. I should have liked to have been able to do so. Privately I thought the Chairman might have to read out loud-and I cannot. I had to refuse. It was a miserable and depressing business and I realise I am now labelled a sugarer, with no sense of duty, and selfish.

To change my thoughts I went to the Forum Cinema and saw "Masquerade in Venice." The spoken conversation was in German and it was translated into English on the screen. My German having rather atrophied, I tried to read the English, but I had not time to finish reading the words before a fresh set of remarks had arrived-neither was there time to look at the pictures as well. And as I was concentrating on reading, this effort shut out the German from my ears. I was done all round, 
felt flustered, depressed and came away knowing very little at all about "Masquerade in Venice."

I am very fond of music and I belong to a choral society. We meet once a week and sing old and modern music. I am an alto I find reading the words and the music almost impossiblefor I have not time and cannot keep up with the rest. I have to let the words go and learn them by heart at home.

The same thing applies to hymns. I always sing the alto part, but alas! for the words of the hymn. But I have not given up trying to include the words, I point my finger to the verse we are singing so that the leap my eyes have to take from the music to the words should make a good landing. I am very conscious of this jump backwards and forwards-music to words and vice versa - and the effort it is, and the time it takes.

I feel a drag on the movement of my eyes to brain.

My husband and I like playing Patience together, but I have to ask him to go slowly for I get swimmy and rattled and fail to follow the moves if he plays fast.

Reading letters is a serious effort, as if reading was not bad enough without also having to cope with what is always to me an undecipherable hand-writing.

I write slowly and do not talk very much and cannot speak in public-not even to open a bazaar. My husband says cheerfully of me: "She is a very intelligent woman and a very badly educated one." My eldest brother says : "Considering how slow she was in reading, and backward, it is wonderful how clever she is now; and that she always had originality and efficiency and did her jobs especially well."

I have one child, born when I was 40 years of age. At her infant school she was considered clever, though slow in reading. She has forged ahead. She is now at a University. In the " vac." I know she reads about a novel a day. But she tells me that when it comes to reading history, she can only read slowly-much more so than the other students.

It has always been a grief to me not being able to read out loud to my girl, from her childhood upwards. I often tried. I am so morbid about her I see only lions in her path.

Some years ago when I went to consult one of your Editors and having blurted out to him that I could not read, he unfolded what was, to me, the new and wonderful story of word-blindness. I came away rejoicing.

"X." 